\title{
AUTOMATIC LINEAMENTS MAPPING AND EXTRACTION IN RELATIONSHIP TO NATURAL HYDROCARBON SEEPAGE IN UGWUEME, SOUTH-EASTERN NIGERIA
}

\author{
Mfoniso Asuquo ENOH ${ }^{1}$, Francis Ifeanyi $\mathrm{OKEKE}^{2}$, Uzoma Chinenye OKEKE ${ }^{3}$ \\ ${ }^{1,2}$ Department of Geoinformatics and Surveying, Faculty of Environmental Studies, \\ University of Nigeria, Nsukka, Nigeria \\ ${ }^{3}$ Department of Surveying and Geoinformatics, Faculty of Environmental Sciences, \\ Nnamdi Azikiwe University, Awka, Nigeria
}

Received 12 February 2020; accepted 12 March 2021

\begin{abstract}
The study focus on the integration of Remote Sensing and Geographic Information System for identification and delineation of lineaments in relation to natural hydrocarbon seepage, which occur in Ugwueme, South-Eastern Nigeria. To achieve this objective, remotely sensed data (ASTER Digital Elevation Model and Landsat 8 OLI/TIRS) were used to depict the surface expression of faults, folds and fractures which are expressed in the form of lineaments. The global positioning system (GPS) was also used for ground verification. The geology map of the study area, which is elucidated in the geology of Nigeria was used to show the distribution of rocks and other geologic structures. The delineation of lineament features was done automatically with the PCI Geomatica while the Rock ware was used to generate the Rose diagram for demonstration of the direction of the extracted lineaments. The classification of the lineaments density and the lineaments intersection analysis were categorized as very low, low, moderate, high and very high classes respectively. Areas classified as very high to high lineaments density are potential zone, which act as conduits for hydrocarbon seepage. The result shows that a total lineament frequency of $947 \mathrm{~km}$ and a total lineament length of $946 \mathrm{~km}$ were delineated from the satellite data. The result further shows that areas with high lineaments density are concentrated in the southwest, south, central and northern part of the study area while areas with low lineament density were found within the eastern part of Ugwueme. The Rose diagram highlight the major trend in the (NE-SW), (N-S) and (NW-SE) directions, and the minor trend in the (W-E) direction. These directional trends depict the directions of lineaments which act as conduits zones for hydrocarbon seepage in the region. The overall findings of the study shows that lineament density, lineament intersection and rose diagrams are concepts applicable in hydrocarbon oil and gas seepages.
\end{abstract}

Keywords: Digital Elevation Model, lineaments, lineament density, lineament intersection, Rose diagram.

\section{Introduction}

The need for studying geologic structures such as lineaments which include faults, joints and fractures cannot be overemphasized. This is because, they do not only act as zones for ores and minerals deposits, but also act as reservoirs for oil, gas and water storage. Lineaments are straight or nearly - straight line features, visible on the earth's surface as faults, folds and fractures which exposes the underlying geologic structure (Hung et al., 2005). These faults, folds and fractures are weak geological plane which play a role as conduits for hydrocarbon oil and gas seepage. The word "lineament" was first used by Hobbs (1904), who describe it as a significant linear landscape that exposes the architecture of different rock basement.
Lineaments was later explained by O'Leary et al. (1976) as mappable surfaces, which aligned in a linear or slightly curvilinear pattern, difference from adjacent features, hence reflecting the subsurface terrain (Han et al., 2018; Manghany et al., 2009). In their own view, Magowe and Carr (1999) define lineaments as surface terrains having expression of joints, fractures and other linear or curvilinear structures occurring on the surface and beneath the earth's surface. In relation to the characteristics of satellite remotely sensed data, Moawad (2008) quoted that lineaments are group of pixels with similar digital numbers. Koch and Mather (1997) documented that lineaments are traces found on the earth's crust, which can be mapped at different scales, ranging from local to continental stage

*Corresponding author. E-mail: enohmfoniso@yahoo.com 
for oil, gas, minerals, ores and for ground water studies (Manghany et al., 2009). The surface expression of faults, fractures, folds and foliations are expressed in the form of lineaments with remotely sensed data, such as satellite imageries and the Digital Elevation Model (DEM) (Solomon, 2003). For decades, the existence of lineaments have been of interest to earth scientists. The attention and interest of linear structures to earth scientists grew rapidly with the introduction of aerial photographs and satellite data. Gupta (2003) reported that the extraction of lineament was first observed with stereo pairs, transparencies and light tables, which was the first generation of satellite data. Lineaments identification on satellite data relates to geological zones of weakness on the earth's crust, which represent fracture traces (Sabins, 1997).

Schumacher (1999) documented that there is a direct relationship between lineament and hydrocarbon seepage (Figure 1). Under high pressure, hydrocarbon oil and gas tend to seep within zones of lineament along fractures and faults of soils and sediments, to form seepages at the earth's surface (Okeke \& Enoh, 2016). According to Shi et al. (2010), the vertical movement and seepage of hydrocarbon oil and gas within zones of lineament along fractures and faults is called Chimney effect. Awadh et al. (2010) quoted that oil and gas which escape from the earth's impermeable reservoir, seep and remain hidden in the subsurface or migrate through zones of lineaments and weak geological planes to form seepages. Okieimen and Okieimen (2005) stated that hydrocarbon that seeps on the earth's surface or near surface often produce changes associated with the soil chemistry.

Remote Sensing have been widely adopted in the field of geoscience, to express the correlation between lineaments and hydrocarbon seepage (Schumacher, 1999). The techniques provide information for identification, mapping and extraction of lineaments within hydrocarbon seepage prone zones at both distinct and regional level. When compared with the conventional methods, remote sensing technique offers a synoptic, systemic, rapid and repetitive area coverage for identification and extraction of lineaments (Leblanc et al., 2003; Tweed et al., 2007). Remote Sensing technique

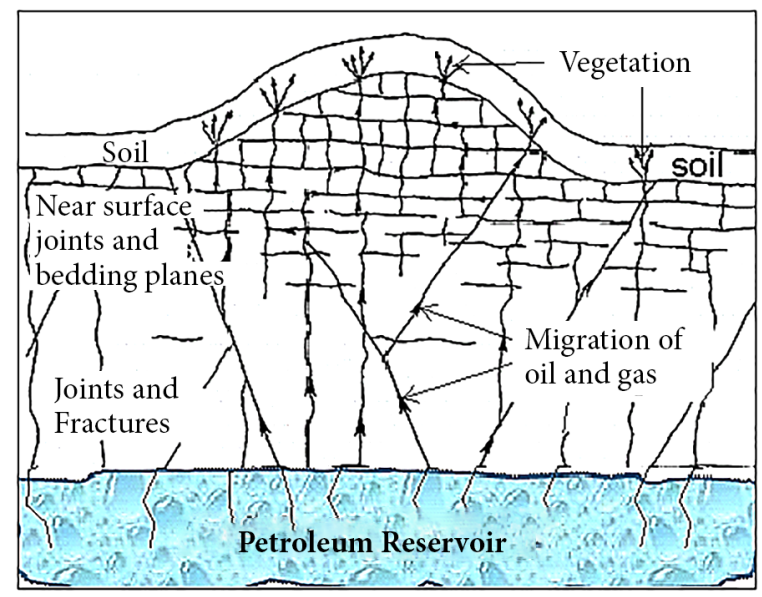

Figure 1. Relation between lineaments and hydrocarbon seepage (Schumacher, 1999) provides an advantage of spatial, spectral and temporal availability of remotely sensed satellite data, which covers a vast and inaccessible locations within a short time frame (Onyedim \& Ocan, 2001). Remotely sensed satellite data, which are acquired from a variable wavelength intervals of electromagnetic spectrum, are more adequate for extracting lineaments than the conventional aerial photographic maps (Casas et al., 2000). Remote Sensing image processing and analysis involves discrimination of lineaments with vary wavelengths intervals (Casas et al., 2000). The various steps involves in the discrimination of lineaments from remotely sensed maps are the enhancement analysis or manual techniques. These techniques are important in lineament analysis for interpretation of areas associated hydrocarbon oil and gas seepage. Remotely sensed data such as satellite imageries and the Digital Elevation Model (DEM) can be used to delineate lineaments by alignment of features. These features include topography, vegetation and soil moisture, which can be studied with tone, color, texture, pattern and topography attributes (Khan \& Glenn, 2006). Three methods have been identified for mapping and extracting lineaments from satellite imageries. These methods are the manual technique (Jordan et al., 2005); the semi - automatic technique (Jordan \& Schott, 2005); and the automatic technique (Rayan, 2013). The automatic technique is the most commonly used method for extracting lineament among researchers. Different automated and semi - automated lineament delineation algorithms exists (Wang \& Howarth, 1990). These algorithms include the Hough Transform, Segment Training Algorithm (STM), PCI LINE and the image objective line extraction (Mallast et al., 2011).

The study was conducted in Ugwueme, in the SouthEastern part of Nigeria. It focus on the integration of Remote Sensing and GIS for automatic delineation of faults, fractures and folds features with Line module from the PCI Geomatica (Hashim et al., 2018). The delineated faults, fractures and folds are represented as lineaments, which may either be linear or curvilinear on remotely sensed data. Thematic maps such as the rose diagram, lineament density map and the lineament intersection map which were prepared from these delineated lineaments often act as conduits for hydrocarbon seepage.

\section{Description of the study area}

\subsection{Location and extent}

Ugwueme is situated on top of Awgu escarpment, in Enugu in the South-Eastern part of Nigeria. Geographically, the region is bound by latitude $6^{\circ} 0^{\prime} 00^{\prime \prime} \mathrm{N}$ and $60^{\circ} 03^{\prime} 00^{\prime \prime} N$ and Longitude $7^{\circ} 24^{\prime} 00^{\prime \prime} E$ and $70^{\circ} 28^{\prime} 00^{\prime \prime}$ $E$ coordinates (Figure 2). The region is bordered by Awgu and Onoli towns in the Eastward direction, Nkwe and Mgbidi towns in the Northward direction and to Lokpanta in the South-West direction. Ugwueme has an aerial coverage of $85.6 \mathrm{~km}$, characterized with low built - up area, with an estimated population of 13000 people (Nigerian Population Commission, 2006). 


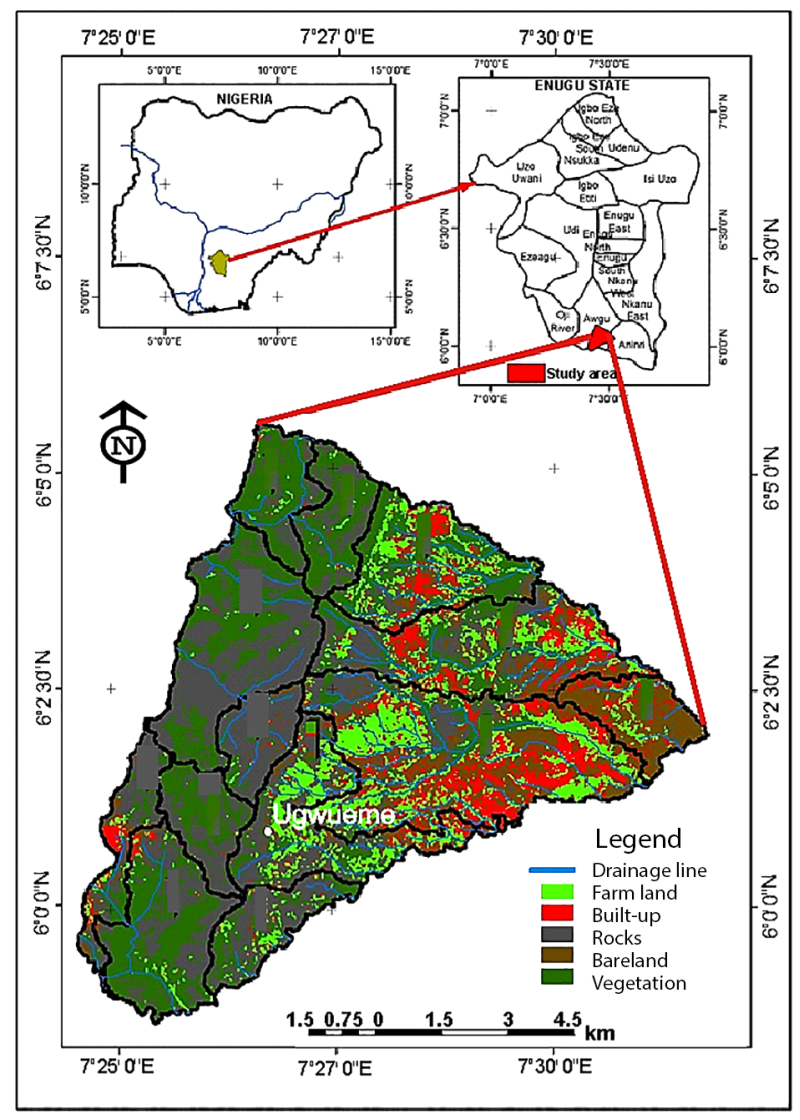

Figure 2. Location map of Ugwueme

\subsection{Climate, drainage, vegetation and soil}

Ugwueme experiences two main climatic conditions, the dry and the wet seasons. During the dry season (November-March), the study area receive little or no raindrops with an average temperature of $26.6{ }^{\circ} \mathrm{C}$ annually. During this period, the region experiences dryness which is associated with the North-East trade wind that blows from the Sahara (Viessman et al., 1972). In the wet season (AprilSeptember), Ugwueme experiences repeated heavy rainfall, with a record of $1800 \mathrm{~mm}$ (Enugu State University of Science and Technology, 2018). This heavy rainfall in the study area often aid flooding, leaching, erosion and infiltration in the zone. Ugwueme is identified with many streams, which assume its sources from the apex of Awgu escarpment. Streams which drain the area are Ogwunnu, Echie, Ndumoku, Obae, Ngene Uhie, Aguta - Lokpanta and Iyiohimiri. These water bodies are dendritic in nature, due to the sedimentary formation of the region. The study area is a large forested area, characterized with tall grasses which remains un - cultivated (Okeke \& Enoh, 2016). The area has mostly ferralitic soils known as Red Earth, which is poorly drained and mainly suitable for cultivation of cash crops.

\subsection{Geological setting}

The geology (lithology) of Ugwueme is highlight in Nigeria's geological map (Figure 4). Stratigraphically, the geologic sequence of Ugwueme, consists of Asu river,
Ezeaku and Awgu deposits. Others are Nkporo, Mamu, Ajali sandstone, Nsukka, Imo shale, Ameki and Benin formation and Alluvium (Reyment, 1965). The Asu river deposits are composed of micaeous shale and ammonite fauna, which were believed to have been developed from basement complex (Kogbe, 1975). The Asu deposits are dark, sandy and fine in nature while the ammonite fauna exhibit an Albian age. Ezeaku deposit consists of hard shale and siltstone, characterized with different colors and different sediments. These color variation in the deposit is between grey and black while the sediments variations is between sandstone and sandy shale. According to Reyment (1965), Ezeaku exhibit a thick deposit, with variation estimated to be up to $1000 \mathrm{~m}$. Beneath the Ezeagu sediment deposit, is the Awgu sediment formations. These formations are rich in ammonites and are characterized with bedded shale, which is estimated to be up to $400 \mathrm{~m}$ thick (Ojoh, 1992). The Nkporo sediment deposit, which is situated above the Awgu deposit is mainly maestrichtian in age. The Owelli sandstone deposits, Enugu and Asata shales deposits are lateral equivalent of Nkporo sediment deposit. Owelli sandstone deposits is estimated to be up to $250 \mathrm{~m}$ thick. These sandstone deposits are mainly ferruginous in nature, characterized with medium and coarse grained sandstones (Simpson, 1954). At the hydrocarbon seepage location, situated in Ugwueme, Owelli sandstone deposit is estimated to be $130 \mathrm{~m}$ thick (Okeke, 2006), settling on the Awgu shale (Figure 3).

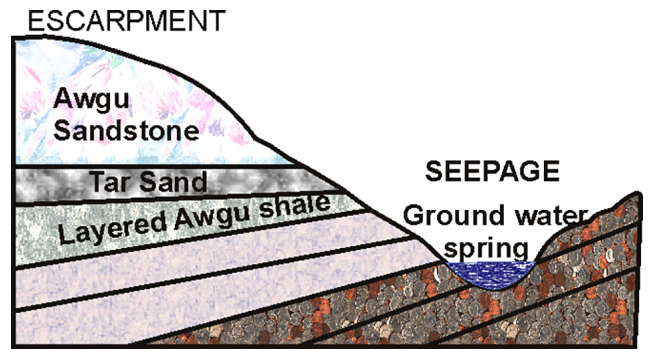

Figure 3. Stratigraphic sequence of Ugwueme (Okeke, 2006)

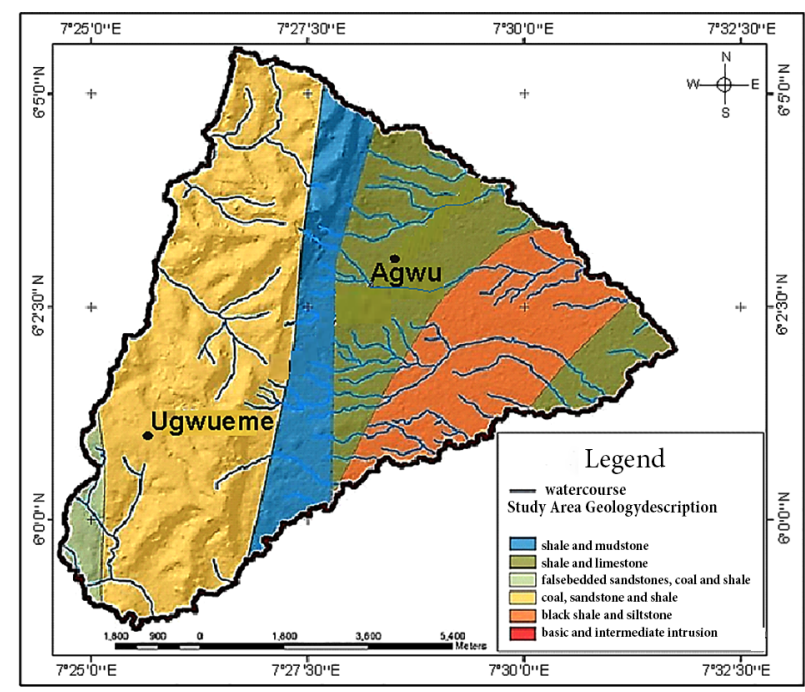

Figure 4. Geology map of Ugwueme 


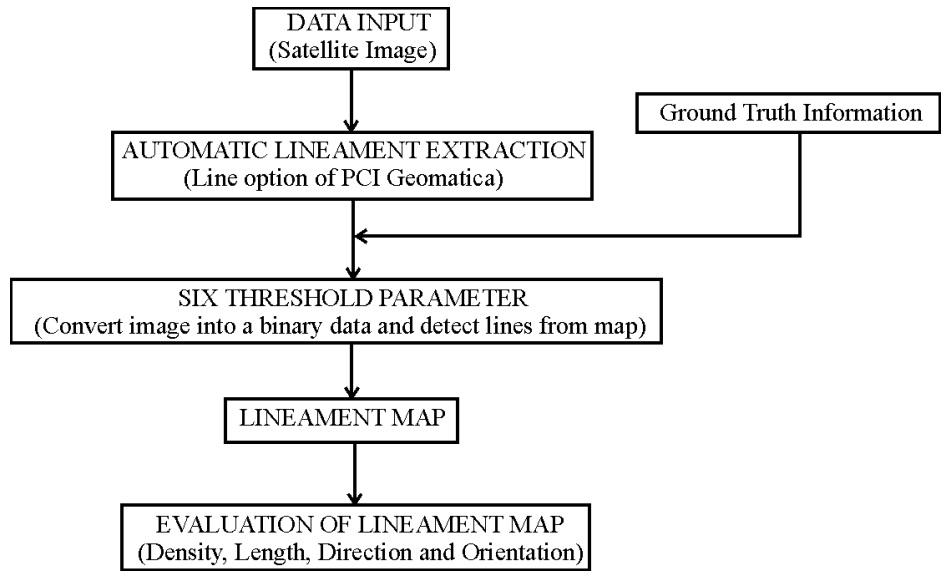

Figure 5. Methodology flow chart of the study

\section{Data and methods}

The first step for the methodology of the study is the selection of the initial input of data for the lineaments extraction. Lineament can be identified and mapped from different sources such as aerial photographs, satellite data and geophysical data etc. In this study, the satellite image was the preferred option for lineament mapping and extraction. The second step for the methodology is the extraction and mapping of lineament from satellite images. The final steps involves the evaluation of the lineament thematic maps. These maps include the lineament density map, direction map, intersection length map and the orientation analysis map. The workflow chart of the study is depict in Figure 5.

\subsection{Data used for the study}

The data utilized for the study were collected from both primary and secondary sources (Table 1). The primary sources involves the use of GPS receiver to obtain the

Table 1. Data acquired for the study

\begin{tabular}{|c|c|c|c|c|c|}
\hline Data & Type & $\begin{array}{l}\text { Path/ } \\
\text { Row }\end{array}$ & Format & $\begin{array}{l}\text { Scale/Re- } \\
\text { solution }\end{array}$ & Source \\
\hline $\begin{array}{l}\text { Landsat } 8 \\
\text { TIRS/OLI }\end{array}$ & $\begin{array}{l}\text { Secon- } \\
\text { dary }\end{array}$ & $\begin{array}{l}188 / 55 \\
\text { and } 56\end{array}$ & Digital & $30 \mathrm{~m}$ & USGS \\
\hline $\begin{array}{l}\text { ASTER } \\
\text { DEM }\end{array}$ & $\begin{array}{l}\text { Secon- } \\
\text { dary }\end{array}$ & & Digital & $\begin{array}{l}1 \text { arc } \\
\text { second }\end{array}$ & USGS \\
\hline $\begin{array}{l}\text { GPS coor- } \\
\text { dinates }\end{array}$ & Primary & & Digital & & $\begin{array}{l}\text { Field } \\
\text { work }\end{array}$ \\
\hline Pictures & Primary & & Analog & & $\begin{array}{l}\text { Field } \\
\text { work }\end{array}$ \\
\hline Geology & $\begin{array}{l}\text { Secon- } \\
\text { dary }\end{array}$ & & Analog & $1: 300,000$ & NGSA \\
\hline $\begin{array}{l}\text { Google } \\
\text { Earth Image }\end{array}$ & $\begin{array}{l}\text { Secon- } \\
\text { dary }\end{array}$ & & Digital & $15 \mathrm{~m}$ & $\begin{array}{l}\text { Google } \\
\text { Earth } \\
(2015)\end{array}$ \\
\hline $\begin{array}{l}\text { Adminis- } \\
\text { trative } \\
\text { map of } \\
\text { Ugwueme }\end{array}$ & $\begin{array}{l}\text { Secon- } \\
\text { dary }\end{array}$ & & Analog & $1: 250,000$ & $\begin{array}{l}\text { OSGOF } \\
(2019)\end{array}$ \\
\hline
\end{tabular}

coordinates of the seepage positions, while the secondary sources include the satellite data, analogue maps covering the study area and the relevant literature which include text books, journals, magazines, weekly newspapers and research websites. The Landsat 8 OLI/TIRS satellite data were downloaded freely at path 188 row 55 and 56 covering the study area from the USGS (2019) official website with earth explorer USGS.gov. It is cloud free and has a spatial resolution of $30 \mathrm{~m}$.

\subsection{Field work}

The field work is an integral part of the study. The field study was observed to validate the hydrocarbon seepage extent in Ugwueme, which was captured with satellite data. The materials adopted for the field study is depict in Table 2.

Table 2. Materials adopted for the field study

\begin{tabular}{|l|l|}
\hline \multicolumn{1}{|c|}{ Materials } & \multicolumn{1}{c|}{ Applications in the study } \\
\hline $\begin{array}{l}\text { Global Positioning } \\
\text { System (GPS) }\end{array}$ & $\begin{array}{l}\text { The GPS was used in the field to } \\
\text { take the geographic coordinate of the } \\
\text { seepage location }\end{array}$ \\
\hline Base map & $\begin{array}{l}\text { The base map serve as a guide for the } \\
\text { study }\end{array}$ \\
\hline Digital camera & $\begin{array}{l}\text { The digital camera was used in the field } \\
\text { for taking photographs of outcrops and } \\
\text { its associated features }\end{array}$ \\
\hline $\begin{array}{l}\text { Field note book, } \\
\text { pen and pencil }\end{array}$ & $\begin{array}{l}\text { These materials were used for recording } \\
\text { purposes }\end{array}$ \\
\hline Geology hammer & $\begin{array}{l}\text { The geologic hammer is a hard steel } \\
\text { hammer, characterized with two ends } \\
\text { and a handle. It was used in the study } \\
\text { for scooping out sample from loose } \\
\text { materials }\end{array}$ \\
\hline
\end{tabular}

\subsection{Major software adopted for the study}

In the study, the software were selected based on their ability to solve existing problems, in order to achieve the predetermined objectives. Sequel to this, the following software (Table 3 ) were adopted for the study. 
Table 3. Major software applicable for the study

\begin{tabular}{|l|l|}
\hline \multicolumn{1}{|c|}{ Software } & \multicolumn{1}{c|}{ Applications in the study } \\
\hline $\begin{array}{l}\text { Arc hydro } \\
\text { software 10.3 }\end{array}$ & $\begin{array}{l}\text { Complementing the display and processing } \\
\text { of the data }\end{array}$ \\
\hline Erdas Imagine & $\begin{array}{l}\text { Pre - lineament delineation, analyzing, } \\
\text { preparation and display of thematic maps }\end{array}$ \\
\hline ENVI 5.0 & $\begin{array}{l}\text { Enhancement of the satellite data, filtering } \\
\text { and computation }\end{array}$ \\
\hline $\begin{array}{l}\text { PCI - } \\
\text { Geomatica 14.0 }\end{array}$ & Automatic lineaments delineation \\
\hline Rockware 14 & To generate the Rose diagram \\
\hline ArcGIS 10.5 & $\begin{array}{l}\text { Spatial modelling, Geospatial analysis, } \\
\text { Vectorization, Geo - database creation }\end{array}$ \\
\hline
\end{tabular}

\subsection{Pre-processing and processing of the satellite data}

The preprocessing of the Landsat 8 OLI/TIRS satellite image were atmospheric and geometric corrections. The acquired satellite data was projected to the Universal Transverse Mercator (UTM) of zone $32 \mathrm{~N}$ on the ellipsoid of World Geodetic System (WGS) 1984. The processing steps had include: layer stacking, sub-setting, geo-referencing, mosaicking and band combinations. The layer stacking tool was utilized to combine the very near infrared (VNIR), short wave infra-red (SWIR) and long wave infra-red (LWIR) bands into a new multiband file that enables the manipulations of all bands simultaneously. The sub-setting tool was utilized to specify the extent of the image for analysis. Sub-setting was observed with software, such as ERDAS Imagine, ARCGIS 10.5 and the PCI Geomatica 14 software. The color composite images of the different bands combinations was done. This is the false color composite (FCC) which combines one visible (VIS), one near-infrared $(N I R)$ and one short-wave infrared band $R(7), G(5)$, and $B(3)$ to depict a large color variation for different surface materials which will aid geological interpretation.

\subsection{Lineament extraction and analysis}

The Erdas Imagine, ENVI and the PCI Geomatica are the most widely used software for automatic lineament extraction from remotely sensed data (Hashim et al., 2018). In this study, the lineament extraction was done with line module associated with PCI Geomatica software. The line module of the PCI Geomatica software reduces subjectivity, save time and aid comparison and validation for lineament extraction (Hashim et al., 2018). The logic of this method is similar to STA, where the total number and total lengths of extracted lineaments depends on the input parameter values, represented by optional digits of the LINE modular in PCI Geomatica software. The algorithm of this modular consists of three stages: The edge detection stage, the threshold stage and the curve extraction stage (Hashim et al., 2018). LINE module of the PCI Geomatica often identify and extract lineaments from an image, before converting these features in vector form with the six optional parameters (Table 4). In the study, the automatic lineaments and extraction were statistically analyzed for the preparation of the lineament length map, lineament density map and lineaments intersection map. The Rockwork 14 software was used in the study to prepare the rose diagram, which indicate the direction of the delineated lineament.

Table 4. Parameters utilized for PCI line module (Hashim et al., 2018)

\begin{tabular}{|c|l|c|}
\hline $\begin{array}{c}\text { Para- } \\
\text { meters }\end{array}$ & \multicolumn{1}{|c|}{ Signification } & $\begin{array}{c}\text { Range } \\
\text { (unit) }\end{array}$ \\
\hline RADI & $\begin{array}{l}\text { Radius to filter, which defines the radius } \\
\text { associated with edge detection filter }\end{array}$ & $\begin{array}{c}0-8192 \\
\text { (pixels) }\end{array}$ \\
\hline GTHR & $\begin{array}{l}\text { Threshold to gradient, which depicts } \\
\text { the threshold design for minimum } \\
\text { gradient for edge pixel so as to acquire } \\
\text { binary image }\end{array}$ & $\begin{array}{c}0-255 \\
\text { (pixels) }\end{array}$ \\
\hline LTHR & $\begin{array}{l}\text { Threshold to length, which defines the } \\
\text { minimum length designated to a curve } \\
\text { as lineaments }\end{array}$ & $\begin{array}{c}0-8192 \\
\text { (pixels) }\end{array}$ \\
\hline FTHR & $\begin{array}{l}\text { Threshold to line fit error, which } \\
\text { highlight the maximum error allowed } \\
\text { to fit polyline with pixel curve }\end{array}$ & $\begin{array}{c}0-8192 \\
\text { (pixels) }\end{array}$ \\
\hline ATHR & $\begin{array}{l}\text { Threshold to angle distance, which } \\
\text { define the maximum angle for uniting } \\
\text { two vectors }\end{array}$ & $\begin{array}{c}0-90 \\
\text { (pixels) }\end{array}$ \\
\hline DTHR & $\begin{array}{l}\text { Threshold to link distance, which } \\
\text { depicts the minimum distance between } \\
\text { two extreme points, for linking two } \\
\text { vectors }\end{array}$ & $\begin{array}{l}0-8192 \\
\text { (pixels) }\end{array}$ \\
\hline
\end{tabular}

\section{Results}

\subsection{Digital Elevation Model (DEM)}

The Digital Elevation Model (DEM) can be acquired from different sources such as the SRTM $(90 \times 90) \mathrm{m}$ global DEM, Advanced Space borne Thermal Emission and Reflection Radiometer (ASTER) $30 \mathrm{~m}$ by $30 \mathrm{~m}$ or by the manual interpolating method (Abdullah et al., 2010; Vittala et al., 2005). This study had adopted the ASTER DEM method for the acquisition of the DEM data. DEM is a numerical surface which store elevation for a particular location on a natural terrain (Figure 6). DEM may store elevation as either Grid or TIN (Carter, 1988). With the grid storage format, DEM store elevation in regular arrays and with the TIN storage format, elevation is stored at irregular distributed points, which connect points with triangles (Carter, 1988). Because TIN are complicated, simple relief shading often prefer the grids storage format instead of TINS (Kratt et al., 2010). With the ArcGIS 10.5 software, the shaded relief image was prepared from DEM whose spatial resolution (30 by 30 ) $\mathrm{m}$ for lineament extraction (Figure 7). The shaded relief images extracted from DEM for the study, has an illumination direction (sun - azimuth) of $315^{\circ} 0^{\prime} 0^{\prime \prime}$ and a solar elevation of $45^{\circ} 0^{\prime} 0^{\prime \prime}$ for automatic lineament extraction which act as channels for hydrocarbon oil and gas seepage. 


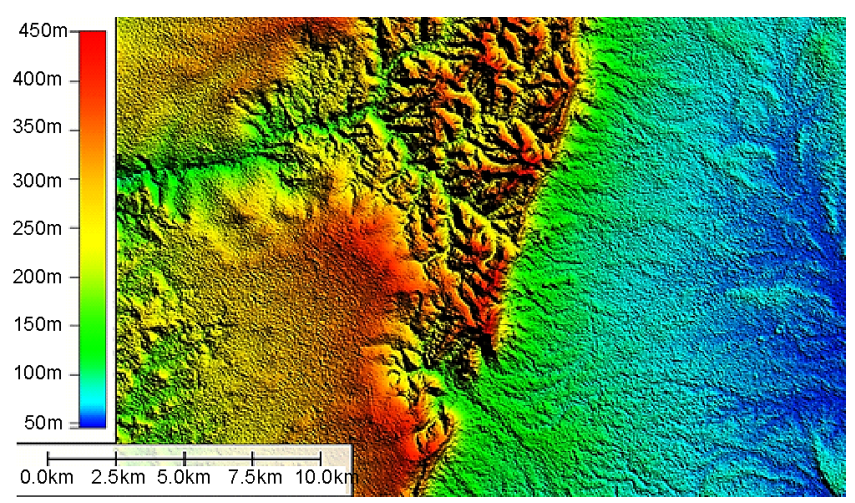

Figure 6. Digital Elevation Model (DEM) of Ugwueme

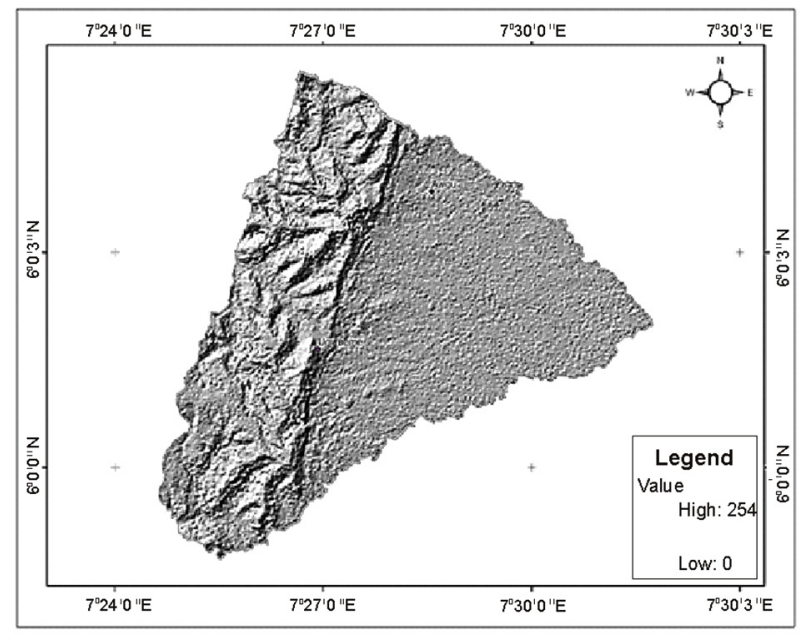

Figure 7. Shaded relief images with illumination directions (sun-azimuth), $315^{\circ} 0^{\prime} 0^{\prime \prime}$, and solar elevation of $45^{\circ} 0^{\prime} 0^{\prime \prime}$

\subsubsection{Fault zone}

Figure 8 depict the surface traces of fault within the study area. Faults are surface traces, expressed in the form of lineaments on remotely sensed data (Solomon, 2003). In the study, the fault traces were delineated from the ASTER Digital Elevation Model (ASTER DEM) and then grouped into four categories as no traces, minor traces, moderate traces and major traces of fault (Table 5). Zones with major traces highlight areas of high lineament density, which are highly prerequisite for hydrocarbon seepage flow. Zones of moderate fault traces depicts areas with moderate lineament density while areas with minor or No traces of fault indicate location with minimal or possibly No lineament features. Areas with No traces of faults, are locations which are not prerequisite for hydrocarbon seepage. Table 5 shows the statistical analysis of the surface traces of faults in Ugwueme. By observation, we see that zones with major traces of fault occupies an area of $119325 \mathrm{~m}^{2}$ which is represented by $17.64 \%$. Zones with moderate traces of fault account for $335638 \mathrm{~m}^{2}$ which yield $49.63 \%$. Zones of minor traces and No traces of faults have an aerial coverage of $156235 \mathrm{~m}^{2}$ and $65132 \mathrm{~m}^{2}$ accounting for $23.1 \%$ and $9.63 \%$ respectively.
Table 5. Statistics of surface trace of fault within Ugwueme

\begin{tabular}{|l|c|c|}
\hline \multicolumn{1}{|c|}{ Classification } & Area $\left(\mathrm{m}^{2}\right)$ & Percentage (\%) \\
\hline No traces of fault & 65132 & 9.63 \\
\hline Minor traces of fault & 156235 & 23.10 \\
\hline Moderate traces of fault & 335638 & 49.63 \\
\hline Major traces of fault & 119325 & 17.64 \\
\hline Total & 676330 & 100 \\
\hline
\end{tabular}

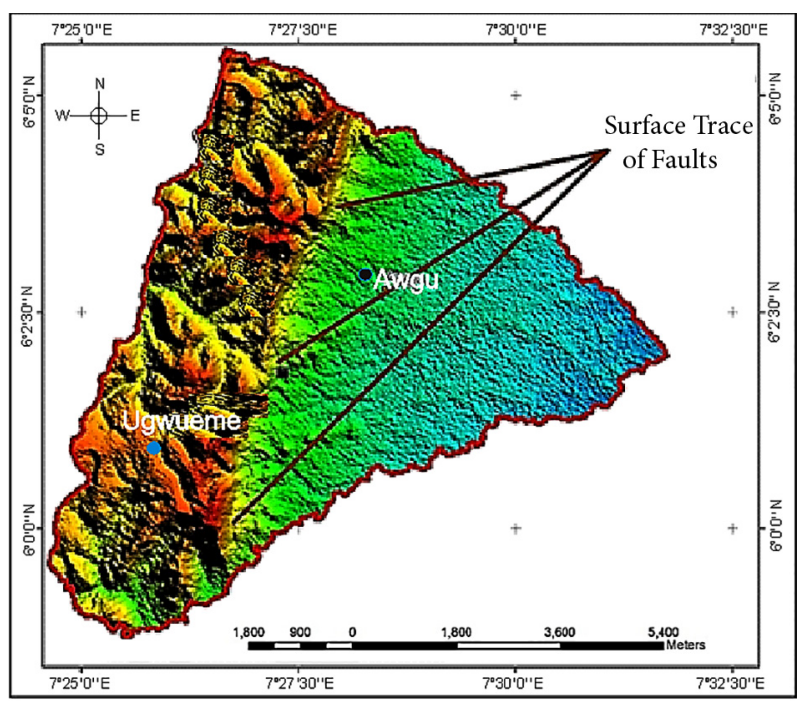

Figure 8. Surface trace of fault within Ugwueme

\subsection{Geology}

Geology plays a vital role in the occurrence of hydrocarbon oil and gas seepage (Solomon, 2003). The geology of an area influences the ways by which lineaments can be mapped and interpreted in an areas associated with hydrocarbon seepage. Different groups of rocks such as Nkporo, Lower coal, false bedded sandston, Awgu - Nde aboh shale, Eze Aku Shale and Asu river have been identified and are elucidate in the geological map covering the study area (Nigeria Geological Survey Agency [NGSA], 2010). The description of the minerals present in each group are Nkporo Shale (Shale and mudstone), Lower Coal (coal, sandstone and shale), false bedded sandstone (false bedded sandstones, coal and shale), Awgu - Nde aboh shale (Shale and limestone), Eze Aku Shale (black shale and siltstone) and Asu river (shale and limestone). Table 6 depicts the classification of lineament frequency and lineament length in each geological feature in the study area. By the classification, Nkporo Shale highlight lineament frequency as $154 \mathrm{~Hz}$ which represent $16.26 \%$ and lineament density as $157 \mathrm{~km}$ which represent $16.60 \%$. Lower Coal depict lineament frequency as $710 \mathrm{~Hz}$, which account for $74.97 \%$ and lineament density as $712 \mathrm{~km}$ for $75.26 \%$. False bedded sandstone are represented with a total frequency of $7 \mathrm{~Hz}$ accounting for $8.34 \%$ and a total lineament density of 70 $\mathrm{km}$ accounting for 7.4\%. Awgu - Nde aboh shale and Eze Aku Shale groups exhibit lineament frequency each for 1 $\mathrm{Hz}$ representing $0.11 \%$ as well as lineament density, each 
for $2 \mathrm{~Hz}$ representing $0.21 \%$ respectively. The Asu river group represent lineament frequency as $2 \mathrm{~Hz}$ accounting for $0.21 \%$ and lineament density of $3 \mathrm{~km}$ accounting for $3 \%$. The overall total lineament frequency of $947 \mathrm{~km}$ and total lineament length of $946 \mathrm{~km}$ have been extracted from the satellite data for the study.

Table 6. Classification of lineaments frequency and lineament length in each geological feature

\begin{tabular}{|l|l|c|c|c|c|}
\hline \multirow{2}{*}{ Name } & \multicolumn{1}{|c|}{ Description } & \multicolumn{2}{c|}{ Frequency } & \multicolumn{2}{c|}{ Length } \\
\cline { 3 - 6 } & & $\mathrm{Hz}$ & $\%$ & $\mathrm{Km}$ & $\%$ \\
\hline $\begin{array}{l}\text { Nkporo Shale } \\
\text { group }\end{array}$ & $\begin{array}{l}\text { Shale and } \\
\text { mudstone }\end{array}$ & 154 & 16.26 & 157 & 16.60 \\
\hline $\begin{array}{l}\text { Lower Coal } \\
\text { measures }\end{array}$ & $\begin{array}{l}\text { Coal, sandstone } \\
\text { and shale }\end{array}$ & 710 & 74.97 & 712 & 75.26 \\
\hline $\begin{array}{l}\text { False bedded } \\
\text { Sandstone }\end{array}$ & $\begin{array}{l}\text { False bedded } \\
\text { sandstones, coal } \\
\text { and shale }\end{array}$ & 7 & 8.34 & 70 & 7.40 \\
\hline $\begin{array}{l}\text { Awgu - Nde } \\
\text { aboh shale }\end{array}$ & $\begin{array}{l}\text { Shale and } \\
\text { limestone }\end{array}$ & 1 & 0.11 & 2 & 0.21 \\
\hline $\begin{array}{l}\text { Eze Aku Shale } \\
\text { group }\end{array}$ & $\begin{array}{l}\text { Black shale and } \\
\text { siltstone }\end{array}$ & 1 & 0.11 & 2 & 0.21 \\
\hline $\begin{array}{l}\text { Asu river } \\
\text { group }\end{array}$ & $\begin{array}{l}\text { Shale and } \\
\text { limestone }\end{array}$ & 2 & 0.21 & 3 & 0.32 \\
\hline & Total & 947 & 100 & 946 & 100 \\
\hline
\end{tabular}

Figures 9 and 10 depicts the lineament length map and lineament frequency map of Ugwueme in each geological feature. The length of lineaments within the study were measured and plotted into grid cell for preparation of the lineament length map. By carefully observing the lineament length map (Figure 9) and the lineament frequency map (Figure 10), we see that the extracted lineaments, are more concentrated in the North-Southern part of the study area than other areas. This observation shows that the North-Southern part of Ugwueme are prerequisite and act as most conduit zones for hydrocarbon seepage.

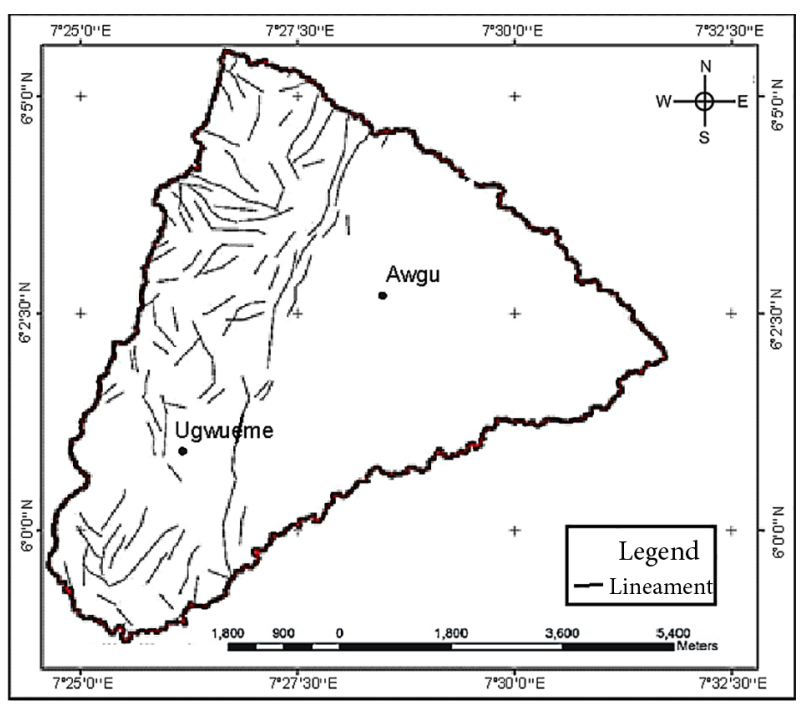

Figure 9. Lineament length map of Ugwueme

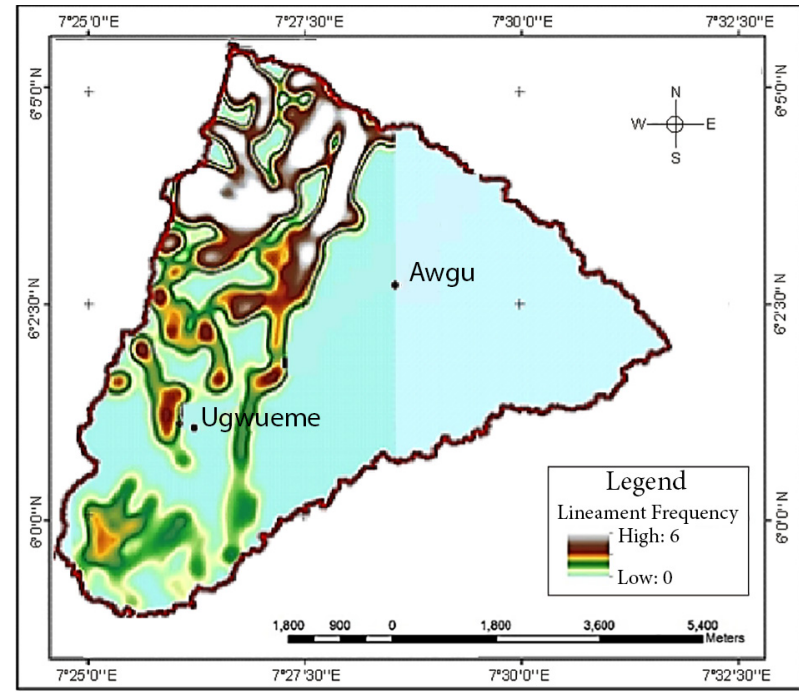

Figure 10. Lineament Frequency map of Ugwueme

\subsection{Lineament density}

The aim of the lineament density analysis is to calculate the frequency of lineament per unit area (Magesh et al., 2012; Yeh et al., 2016). The analysis is used to produce a map which shows the concentration of the lineaments within the grid cell in the study area. In the study, lineament density map was produced with the spatial analyst tool which is elucidated in the ARCGIS 10.5 software by counting the lines per unit area, and then plot them in the grid center with the same tool. The line designated within the neighborhood is valid during density calculation. If the line falls outside the neighborhood for a particular cell, it is labeled no data. Table 7 depicts the lineament density classification categorized from very high to high, moderate and from very low to low lineament density for hydrocarbon seepage. The classification result shows that areas with very high lineament density represent $1774 \mathrm{~m}^{2}$ which account for $0.26 \%$, areas with high lineament density depicts $19476 \mathrm{~m}^{2}$ accounting for $2.82 \%$, areas with moderate lineament density highlight $105132 \mathrm{~m}^{2}$ yielding $15.18 \%$, areas with low and low lineament densities account for $198175 \mathrm{~m}^{2}$ and $368137 \mathrm{~m}^{2}$ yielding $28.61 \%$ and $53.15 \%$ respectively.

Table 7. Classification of lineament density of Ugwueme

\begin{tabular}{|l|c|c|}
\hline \multicolumn{1}{|c|}{ Classification } & Area $\left(\mathrm{m}^{2}\right)$ & Percentage (\%) \\
\hline Very low lineament density & 368137 & 53.15 \\
\hline Low lineament density & 198175 & 28.61 \\
\hline Moderate lineament density & 105132 & 15.18 \\
\hline High lineament density & 19476 & 2.81 \\
\hline Very high lineament density & 1774 & 0.26 \\
\hline Total & 692694 & 100 \\
\hline
\end{tabular}

Lineament density map of all - round directions is produced and depicted with grids (Figure 11). The Lineament density map indicate that high lineament density is 


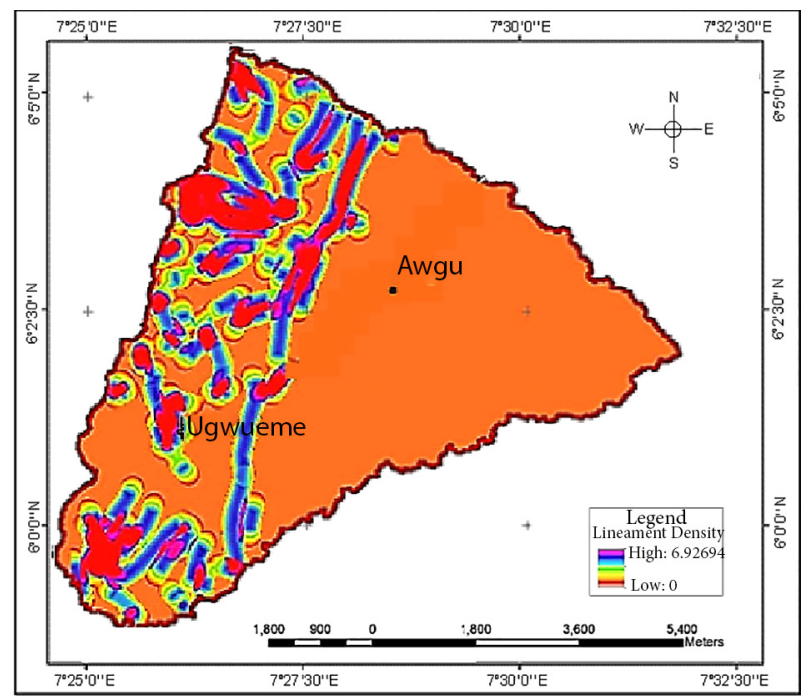

Figure 11. Lineament density map of Ugwueme

more pronounced in the North-South zone of the study area as compared to other regions. Area with very high to high lineament density are most conduit zones for hydrocarbon seepage.

\subsection{Lineament intersection density}

Lineament intersection density is represented as the total number of intersection lineament, estimated per unit area (Yeh et al., 2016). In this study, the lineament intersection density was observed by plotting the intersection of two or more lineaments, considering it as points and then contour the points to produce different degree of fracture. Table 8 depicts the classification of lineament intersection for the study. The classification result was categorized from very low to low, moderate and from high to very high lineament intersection density. Areas with very high lineament intersection density were categorized as $1781 \mathrm{~m}^{2}$ representing $0.26 \%$, areas with high lineament intersection density accounted for $19325 \mathrm{~m}^{2}$ yielding $2.79 \%$, areas with moderate lineament intersection density produce $85132 \mathrm{~m}^{2}$ resulting in $12.29 \%$, while areas with low and very low lineament intersection density accounted for $141318 \mathrm{~m}^{2}$ and $445138 \mathrm{~m}^{2}$ representing $20.40 \%$ and $64.26 \%$ respectively.

Table 8. Classification of Lineament Intersection of Ugwueme

\begin{tabular}{|l|c|c|}
\hline \multicolumn{1}{|c|}{ Classification } & $\begin{array}{c}\text { Area } \\
\left(\mathrm{m}^{2}\right)\end{array}$ & $\begin{array}{c}\text { Percentage } \\
(\%)\end{array}$ \\
\hline Very low lineament intersection & 445138 & 64.26 \\
\hline Low lineament intersection & 141318 & 20.40 \\
\hline Moderate lineament intersection & 85132 & 12.29 \\
\hline High lineament intersection & 19325 & 2.79 \\
\hline Very high lineament intersection & 1781 & 0.26 \\
\hline Total & 692694 & 100 \\
\hline
\end{tabular}

Figure 12 depict the lineament intersection density map per unit area for the study. The lineament intersection map exposes the hidden underlying configuration, which appears as linear intersection features (Yeh et al., 2016). The aim of the intersection density map is to determine the areas which are of diverse fracture orientation. The intersection density map is shown as a plain map, if the fractures don't intersect within the area. By observing the lineament intersection map (Figure 12), we see that lineament intersections are more concentrated in the NorthSouth region of the study area. Towards the eastern part of the study area, the lineament intersection is very low to low, and in some cases, it does not exist. Area with very high to high lineament density intersection are most conduit zones for hydrocarbon seepage.

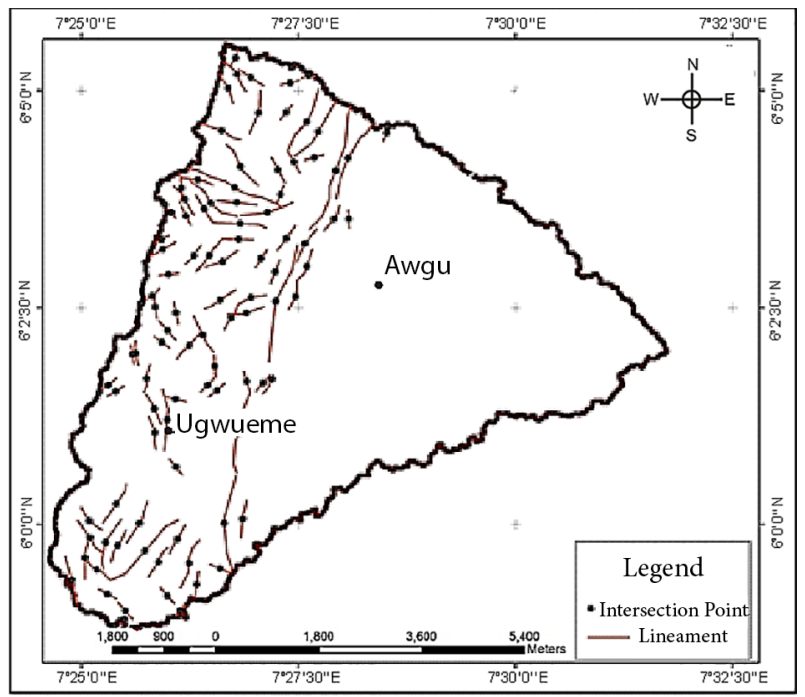

Figure 12. Lineament intersection map of Ugwueme

\subsection{Orientation analysis}

Lineament orientation are often determined with Rose diagrams (Yeh et al., 2016). The Rose diagram tool which is elucidated in the Rose work software is often used to prepare the Rose diagram (Figure 13). The Rose diagram

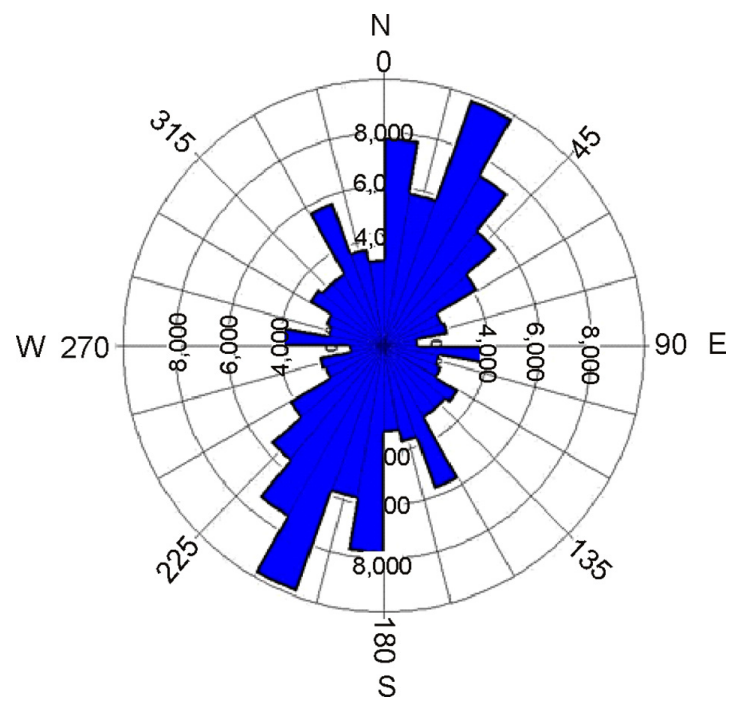

Figure 13. The Rose diagram depicting the distribution of delineated lineaments 
Table 9. Statistical summary of lineament

\begin{tabular}{|l|c|}
\hline \multicolumn{2}{|c|}{ Statistical summary } \\
\hline Calculation method & length \\
\hline Class interval & 10.0 degrees \\
\hline Min. Length fittering & deactivated \\
\hline Max. Length fittering & deactivated \\
\hline Azimuth fittering & deactivated \\
\hline Data type & bidirectional \\
\hline Population & 233 \\
\hline Total lenth of all lineations & $154,710.79$ \\
\hline Maximum bin population & 25.0 \\
\hline Mean bin population & 12.94 \\
\hline Standard deviation of bin population (\%) & 6.27 \\
\hline Maximum bin length (\%) & 5.36 \\
\hline Mean bin length (\%) & 2.78 \\
\hline Standard deviation of bin population (\%) & 1.34 \\
\hline Maximum bin length (\%) & $9,814.23$ \\
\hline Mean bin length (\%) & $4,297.52$ \\
\hline Standard deviation of bin lengths (\%) & $2,242.94$ \\
\hline Maximum bin length (\%) & 6.34 \\
\hline Mean bin length (\%) & 2.78 \\
\hline Standard deviation of bin lengths (\%) & 1.45 \\
\hline Vector mean & 16.4 degrees \\
\hline & 196.39 degrees \\
\hline Confidence interval & $(80$ percent) \\
\hline & 0.29 \\
\hline R-mag & degrees \\
\hline & \\
\hline
\end{tabular}

in the study depicts the directional frequency of the automatic extracted lineament over the investigated area. These diagram highlight two important trends for directional orientation. These trends are the major trend, explicit in the (NE-SW), (N-S) and (NW-SE) directions, and the minor trends indicated in the (W-E) direction. The directional trends of the Rose diagram are utilized for testing the distribution of faults, folds and fractures, which are expressed as lineament features and which act as conduits for hydrocarbon seepage. Table 9 depicts the statistical summary of the extracted lineament for the study area.

\section{Conclusions and discussions}

The study shows that Remote Sensing and GIS are cost effective tools for mapping geological features such as lineaments, which include faults, fractures and folds. Hydrocarbon oil and gas which escape from the earth's impermeable reservoir often flow at high pressure along zones of faults and fractures to form seepages. In this study, remote sensing was integrated with GIS for identification and extraction of lineaments in relations to natural hydrocarbon seepage in Ugwueme, South-Eastern Nigeria. Lineaments delineated from remotely sensed data were used for preparation of the fault zone map, Rose diagram, lineament density map and lineament intersection maps. These maps exposes the subsurface configuration which exist in the form of linear features and which act as conduits for hydrocarbon seepage. The Rose diagram depicts the NESW, N-S and NW-SE major trend orientation and the W-E minor trend orientation. These directional trends are the determining factors for testing the distribution of lineaments, which are channels for the flow of hydrocarbon oil and gas. The lineament density map and the lineament intersection map were classified as very high, high, moderate, low and very low zones for hydrocarbon seepage. Zones of very high to high lineament density were diagnosed as areas of high degree of fractures and folds, which are prerequisite for hydrocarbon seepage. The lineament density map shows that areas of very high, high, moderate, low and very low lineament densities were identified as $1774 \mathrm{~m}^{2}, 19476 \mathrm{~m}^{2}, 105132 \mathrm{~m}^{2}, 198175 \mathrm{~m}^{2}$ and $368137 \mathrm{~m}^{2}$ which represent $0.26 \%, 2.81 \%, 15.18 \%, 28.61 \%$ and $53.15 \%$ respectively. Similarly, the lineament intersection map shows that areas of very high, high, moderate, low and very low lineament intersections were categorized as $1781 \mathrm{~m}^{2}, 19325 \mathrm{~m}^{2}, 85132 \mathrm{~m}^{2}, 141318 \mathrm{~m}^{2}$ and $445138 \mathrm{~m}^{2}$ which yields $0.26 \%, 2.79 \%, 12.29 \%, 20.40 \%$ and $64.26 \%$ respectively. The study shows that zones of major traces of fault, high lineaments density and high intersection density are most conduits areas for hydrocarbon seepage.

\section{Disclosure statement}

The authors declare that no conflict of interest exist.

\section{References}

Abdullah, A., Akhir, J. M., \& Abdullah, I. (2010). Automatic mapping of lineaments using shaded relief images derived from Digital Elevation Model (DEM) in the Maran - Sungai Lembing area, Malaysia. Electronic Journal of Geotechnical Engineering, 15(1), 949-957.

Awadh, S. M., Al-Ameri, T. K., Jassim, S. Y., \& Bayraktutan, M. S. (2010). Fluid inclusions usage assessing oil migration in Duhok, North Iraq. Positioning, 1, 42-49.

https://doi.org/10.4236/pos.2010.11005

Carter, R. W. (1988). Coastal environments: an introduction to the physical ecological and cultural systems of coastlines (pp. 335346). Academic.

Casas, A. M., Cortés, A. L., Maestro, A., Soriano, M. A., Riaguas, A., \& Bernal, J. (2000). LINDENS: A program for lineament length and density analysis. Computers \& Geosciences, 26(9-10), 1011-1022.

https://doi.org/10.1016/S0098-3004(00)00017-0

Enugu State University of Science and Technology. (2018). Rain data. Geography and meteorology Department, Enugu State University of Science and Technology, Enugu, Nigeria.

Google Earth. (2015). https://earth.google.com/web/

Gupta, R. P. (2003). Remote sensing geology (2 ${ }^{\text {nd }}$ ed.). Springer. https://doi.org/10.1007/978-3-662-05283-9

Han, L., Liu, Z., Ning, Y., \& Zhao, Z. (2018). Extraction and analysis of geological lineaments, combining a DEM and remote 
sensing images from the northern Baoji loess area. Advances in Space Research, 62(9), 2480-2493.

https://doi.org/10.1016/j.asr.2018.07.030

Hashim, M., Misbari, S., \& Pour, A. B. (2018). Landslide mapping and assessment by integrating Landsat-8, PALSAR-2 and GIS techniques: a case study from Kelantan state, Peninsular Malaysia. Journal of the Indian Society of Remote Sensing, 46(2), 233-248. https://doi.org/10.1007/s12524-017-0675-9

Hobbs, W. H. (1904). Lineaments of the Atlantic border region. Geological Society of America Bulletin, 15(1), 483-506. https://doi.org/10.1130/GSAB-15-483

Hung, L. Q., Batelaan, O., \& de Smedt, F. (2005). Lineament extraction and analysis, comparison of LANDSAT ETM and ASTER imagery. Case study: Suoimuoi tropical karst catchment, Vietnam. Proceedings of SPIE, 5983.

https://doi.org/10.1117/12.627699

Jordan, G., \& Schott, B. (2005). Application of wavelet analysis to the study of spatial pattern of morphotectonic lineaments in digital terrain models. A case study. Remote Sensing of Environment, 94(1), 31-38.

https://doi.org/10.1016/j.rse.2004.08.013

Jordan, G., Meijninger, B. M. L., van Hinsbergen, D. J. J., Meulenkamp, J. E., \& van Dijk, P. M. (2005). Extraction of morphotectonic features from DEMs: Development and applications for study areas in Hungary and NW Greece. International Journal of Applied Earth Observation and Geoinformation, 7(3), 163-182. https://doi.org/10.1016/j.jag.2005.03.003

Khan, S. D., \& Glenn, N. F. (2006). New strike-slip faults and litho-units mapped in Chitral (N. Pakistan) using field and ASTER data yield regionally significant results. International Journal of Remote Sensing, 27(20), 4495-4512. https://doi.org/10.1080/01431160600721830

Koch, M., \& Mather, P. M. (1997). Lineament mapping for groundwater resource assessment: A comparison of digital Synthetic Aperture Radar (SAR) imagery and stereoscopic Large Format Camera (LFC) photographs in the Red Sea Hills, Sudan. International Journal of Remote Sensing, 18(7), 1465-1482. https://doi.org/10.1080/014311697218223

Kogbe, C. A. (1975). The cretaceous and Paleogene sediments of southern Nigeria. In C. A. Kogbe (Ed.), Geology of Nigeria. University of IEE Press.

Kratt, C., Calvin, W. M., \& Coolbaugh, M. F. (2010). Mineral mapping in the Pyramid Lake basin: Hydrothermal alteration, chemical precipitates and geothermal energy potential. Remote Sensing of Environment, 114(10), 2297-2304. https://doi.org/10.1016/j.rse.2010.05.006

Leblanc, M., Leduc, C., Razack, M., Lemoalle, J., Dagorne, D., \& Mofor, L. (2003). Application of remote sensing and GIS for groundwater modelling of large semi-arid areas: example of the lake Chad Basin, Africa. In Hydrology of Mediterranean and Semiarid Regions Conferences (pp. 186-192). Montpellier, France.

Magesh, N. S., Chandrasekar, N., \& Soundranayagam, J. P. (2012). Delineation of groundwater potential zones in Theni district, Tamil Nadu, using remote sensing, GIS and MIF techniques. Geoscience Frontiers, 3(2), 189-196. https://doi.org/10.1016/j.gsf.2011.10.007

Magowe, M., \& Carr, J. R. (1999). Relationship between lineaments and ground water occurrence in Western Botswana. Ground Water, 37(2), 282-286. https://doi.org/10.1111/j.1745-6584.1999.tb00985.x

Mallast, U., Gloaguen, R., Geyer, S., Rodiger, T., \& Siebert, C. (2011). Semi-automatic extraction of lineaments from remote sensing data and the derivation of groundwater flow-paths.
Hydrology and Earth System Sciences Discussions, 8, 13991431. https://doi.org/10.5194/hessd-8-1399-2011

Manghany, M., Mansor, S., \& Hashim, M. (2009). Geologic mapping of the United Arab Emirates using multispectral remotely sensed data. American Journal of Engineering and Applied Sciences. https://doi.org/10.3844/ajeassp.2009.476.480

Moawad, B. M. (2008). Applications of remote sensing and geographic information systems in geomorphological studies: Safaga-El Quseir area, Red Sea, Egypt as an example. VDM Verlag Dr Muller.

Nigeria Geological Survey Agency. (2010). The Geological map of Nigeria, Abuja. https://ngsa.gov.ng/geological-maps/

Nigerian Population Commission. (2006). 2010 Projection.

O'Leary, D. W., Friedman, J. D., \& Pohn, H. A. (1976). Lineament, linear, lineation: some proposed new standards for old terms. Geological Society of America Bulletin, 87(10), 1463-1469.

https://doi.org/10.1130/0016-7606(1976)87<1463:LLLSPN> 2.0.CO;2

Ojoh, K. A. (1992). The southern part of Benue Trough (Nigeria) Cretaceous stratigraphy, basin analysis, paleo-oceanography and geodynamics evolution in equatorial domain of the South Atlantic. The Nigerian Association of Petroleum Explorationists Bulletin, 7, 131-152.

Okeke, F. I., \& Enoh, M. A. (2016). Analyzing the effect of hydrocarbon seepage on vegetation in Ugwueme town, Awgu Local Government Area of Enugu State using Normalized Differencing Vegetation Index (NDVI) threshold classification method. International Journal of Multidisciplinary Research and Modern Education, 2(2), 2454-6119.

Okeke, H. C. (2006). Elemental and physicochemical analysis of crude oil extract from Ugwueme tar sand deposit. https://www. globalacademicgroup.com/journals/the\%20nigerian\%20academic\%20forum/Okeke80.pdf

Okieimen, C. O., \& Okieimen, F. E. (2005). Bioremediation of crude oil- polluted soil: effect of poutry droppings and natural rubber processing sludge application on biodegrading of petroleum hydrocarbons. Environmental Sciences, 12(1), 1-8.

Onyedim, G. C., \& Ocan, O. O. (2001). Correlation of SPOT imager lineaments with geological fractures in parts of Ilesha area, southern Nigeria. Journal of Mining and Geology, 37, 15-22.

OSGOF. (2019). Office of the Surveyor General of the Federation. Abuja, Nigeria. https://osgof.gov.ng/

PCI Geomatica. (2015). Users' manual.

Reyment, R. A. (1965). Aspects of the geology of Nigeria (pp. 4860). University of Ibadan Press.

Sabins, F. (1997). Remote sensing: principles and interpretation ( $2^{\text {nd }}$ ed.). Freeman.

Schumacher, D. (1999). Surface geochemical exploration for petroleum. In Treatise of Petroleum Geology handbook (pp. 18-27). American Association of Petroleum Geologist. https://doi.org/10.1306/TrHbk624C19

Shi, P. L., Fu, B. H., \& Ninomiya, Y. (2010). Detecting lithology features from ASTER VNIR - SWIR multispectral data in the arid region: A case study in the Eastern Kalpin uplift, Southern Tian Shan. Chinese Journal of Geology, 45(1), 333-347.

Simpson, A. (1954). The Nigerian coalfield: The geology of parts of Onitsha, Owerri and Benue provinces. Bulletin of the Geological Survey of Nigeria, 24.

Solomon, S. (2003). Remote sensing and GIS: Applications for groundwater potential assessment in Eritrea [PhD thesis]. Department of Environment and Natural Resources Information System, Royal Institute of Technology, Sweden. 
Thannoun, R. G. (2013). Automatic extraction and geospatial analysis of lineaments and their tectonic significance in some areas of Northern Iraq using remote sensing techniques and GIS. International Journal of Enhanced Research in Science Technology \& Engineering, 2(2), 1-11.

Tweed, S. O., Leblanc, M., Webb, J. A., \& Lubczynski, M. W. (2007). Remote sensing and GIS for mapping groundwater recharge and discharge areas in salinity prone catchments, southeastern Australia. Hydrogeology Journal, 15, 75-96. https://doi.org/10.1007/s10040-006-0129-x

USGS. (2019). United States Geological Survey database. https://earthexplorer.usgs.gov

Viessman, M., Harbaught, T. E., \& Knapp, J. W. (1972). Introduction to hydrology. Education publishers.

Vittala, S., Govindaiah, S., \& Gowda, H. H. (2005). Evaluation of groundwater potential zones in the sub-watersheds of north Pennar river basin around Pavagada, Karnataka, India, using remote sensing and GIS techniques. Journal of the Indian Society of Remote Sensing, 33(4), 483-493. https://doi.org/10.1007/BF02990733

Wang, J., \& Howarth, P. J. (1990). Use of the Hough transform in automated lineament detection. IEEE Transactions on Geoscience and Remote Sensing, 28(4), 561-567. https://doi.org/10.1109/TGRS.1990.572949

Yeh, H.-F., Cheng, Y.-S., Lin, H.-I., \& Lee, C.-H. (2016). Mapping groundwater recharge potential zone using a GIS approach in Hualian River, Taiwan. Sustainable Environment Research, 26(1), 33-43. https://doi.org/10.1016/j.serj.2015.09.005 